\title{
Improvement in Abnormal Secretion of Thyrotropin and Gonadotropin after Restoration of Serum Calcium in Pseudohypoparathyroidism
}

\author{
Hitoshi SUZUKI, KIKUO KASAI, SHIN-ICHI SHIMODA, \\ KATSUMI MORI*, AND MATSUEI MIYASAKA* \\ Department of Endocrinology, Internal Medicine, Psychiatry*, \\ Dokkyo University School of Mẹdicine, Mibu, Tochigi 321-02
}

\begin{abstract}
A 25 yr-old woman patient was admitted because of convulsion. The diagnosis of pseudohypoparathyroidism was made on the bais of typical stigmata, lowered serum calcium, increased serum phosphorus and parathyroid hormone levels, and defective response in urinary excretion of cyclic AMP and phosphorus to exogenous parathyroid extract. Endocrine studies performed in the hypocalcemic state revealed several abnormalities of the pituitary gland such as an exaggerated response of TSH to TRH, high basal levels and exaggerated responses of $\mathrm{LH} / \mathrm{FSH}$ and a blunted $\mathrm{GH}$ response to arginine- $\mathrm{HCl}$, while there was no clinical evidence of hypothyroidism and hypogonadism. These abnormalities of anterior pituitary function were normalized after the restoration of normocalcemia by using $1 \alpha$-hydroxy-cholecalciferol.

These results suggest that some endocrine abnormalities observed in pseudohypoparathyroidism might be functional and reversible disorders secondary to hypocalcemia rather than genetic ones.
\end{abstract}

Pseudohypoparathyroidism is a disorder characterized by hypocalcemia, hyperphosphatemia, and defective calcemic and phosphaturic responses to exogenously administered parathyroid hormone (Albright et al., 1942; Chase et al., 1969; Drezner et al., 1973). In most cases the patients also demonstrated mental retardation and characteristic skeletal and somatic deformities such as brachydactyly, round face and short stature (Albright et al., 1942). Because of defective renal responses to parathyroid hormone as determined by the excretion of cylic AMP (Chase et al., 1969) and phosphorus (Drezner et al., 1973), the metabolic defect in this disorder may be related to abnormalities not only in the specific renal receptor-adenylate cyclase system responsive to parathyroid hormone, but also

Received September 16, 1981 in the post-cyclic AMP steps. On the other hand, the occasional association of hypothyroidism with pseudohypoparathyroidism has been reported (Winnacker et al., 1967; Zisman et al., 1969; Marx et al., 1971; Werder et al., 1975). The cause of hypothyroidism was though to lie in selective deficiency of thyrotropin or a primary thyroid disorder. Recent studies of other endocrine functions in pseudohypoparathyroidism also revealed isolated or multiple abnormalities of anterior pituitary hormone secretion (Carlson et al., 1977; Wolfsdorf et al., 1978; Shapiro et al., 1980).

In the present report, we describe a case of pseudohypoparathyroidism in which a diminished $\mathrm{GH}$ response and exaggerated responses of TSH and $\mathrm{LH} / \mathrm{FSH}$ to each secretagogue were observed in the hypocalcemic state. However, these abnormal responses of anterior pituitary hormones were normalized 
after correction of the serum calcium level by the administration of $1 \alpha$-hydroxy-cholecalciferol.

\section{Case report}

A patient, a 25 yr-old woman, was admitted to Dokkyo University Hospital on February 14, 1978, because of convulsions. Grand mal seizures were first observed at the age of $8 \mathrm{yr}$. Subsequently, psychomotor seizure occurred sometimes during her junior high school period and then she received anticonvulsants. At the age of $15 \mathrm{yr}$, she was admitted to a hospital for bilateral cataract extractions. Her menarche occurred at the age of $14 \mathrm{yr}$ and was followed by a normal mestrual cycle. During 2 years before admission, she stopped taking medication. On her admission, there were no complaints of paresthesias, cold intolerance, constipation or dry skin. Physical examination revealed the patient as slightly obese (height; $151 \mathrm{~cm}$, weight; $56 \mathrm{~kg}$ ) and round-faced but without bradydactyly. There was no evidence of subcutaneous calcification, and she did not have a goiter. The blood pressure was $98 / 64 \mathrm{mmHg}$. Chvostek and Trousseau signs were positive. Examination of heart and lungs was within normal limit. The remainder of the physical examination produced negative results. Laboratory studies showed a hematocrit of 35 per cent, hemoglobin of $12.4 \mathrm{~g}$ per $100 \mathrm{ml}$ and a white cell count of 5800 with a normal differential. The blood urea nitrogen, fasting blood sugar, serum cholesterol, serum chloride, serum sodium and serum potassium levels were within normal limits. The serum calcium was $2.4 \mathrm{mEq}$ per liter, serum phosphorus $5.9 \mathrm{mg}$ per $100 \mathrm{ml}$ and serum magnesium $1.8 \mathrm{mg}$ per $100 \mathrm{ml}$. Liver function tests gave almost normal results. The alkaline phosphatase was 14.9 King-Armstrong units and its isozyme study showed that alkaline phosphatase- 2 was dominant and though to be originated from the liver. The serum antithyroid anti- body was undetectable. An electrocardiogram showed a QT interval of 0.42 seconds at a rate of 62.5 per minute. The skull roentogenogram and the brain CT scan showed marked calcification in the basal ganglia but other $\mathrm{x}$ ray examinations showed no ectopic calcification in the soft tissue or shortening of the metacarpals. The karyotype obtained from a culture of peripheral leukocytes showed a $46 \mathrm{XX}$ pattern. The serum concentration of parathyroid hormone was $0.68 \mathrm{ng}$ per $\mathrm{ml}$ (normal range; $\sim 0.5 \mathrm{ng}$ per $\mathrm{ml}$ ). The Ellsworth-Howard test was then performed by using 200 USP units of bovine parathyroid extract (Eli Lilly Co.). The patient showed diminished response in urinary cyclic AMP and phosphorus excretion to parathyroid extract. The net increase in 2 hours phosphorus excretion after parathyroid extract was 14.82 $\mathrm{mg}$ and that in 1 hour cylic AMP excretion was $0.16 \mu$ mole (Fig. 1). A clinical diagnosis of pseudohypoparathyroidism type I was then made. Evaluation of the anterior pituitary function was performed under the hypocalcemic state (see "Methods"). After the initial study, the patient received $1 \alpha$-hydroxy-cholecalciferol $1 \mu \mathrm{g}$ daily, then the dose was gradually increased to $3 \mu \mathrm{g}$ to maintain the serum calcium level within the normal range. Pituitary functions were reevaluated after correction of hypocalcemia.

\section{Methods}

In order to evaluate the endocrine function, the following tests were performed after an overnight fasting. Thyrotropin releasing hormone (synthetic TRH, Tanabe Seiyaku Co., Osaka, Japan) or luteinizing hormone releasing hormone (synthetic LH-RH, Daiichi Seiyaku Co., Tokyo Japan) was given as an intravenous bolus of $500 \mu \mathrm{g}$ or $100 \mu \mathrm{g}$, respectively. Thirty grams of arginine- $\mathrm{HCl}$ were infused intravenously over 30 minutes to evaluate growth hormone secretion. Serum samples were obtained at intervals before and for 2 hours after intravenous administration of each secretagogue.

Pituitary hormones were measured in specific radioimmunoassay by means of commercially available kits. The radioimmunoassay kits for growth 


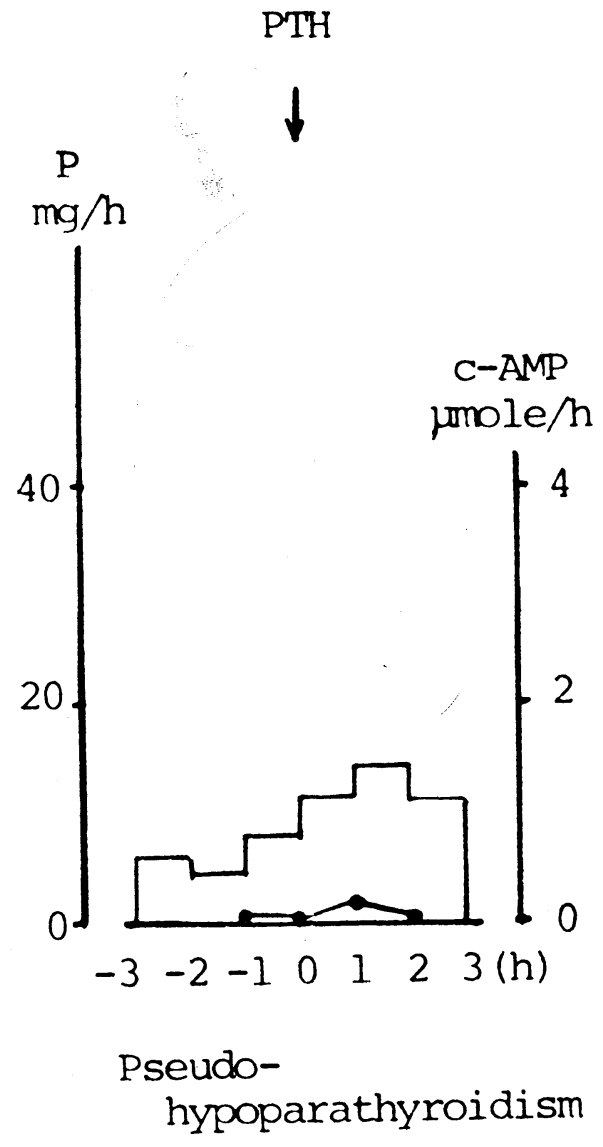

Fig. 1. Effect of exogenously administered PTH on urinary excretion of phosphorus (column) and cyclic AMP (closed circle) (Ellsworth-Howard test).

hormone $(\mathrm{GH})$, follicle stimulating hormone (FSH), and luteinizing hormone (LH) were supplied by Dainabot RI Lab., Tokyo, Japan. Serum thyrotropin (TSH) was measured with a radioimmunoassay kit supplied by Daiichi RI Lab., Tokyo, Japan. Serum parathyroid hormone was measured with a carboxyterminal radioimmunoassay kit supplied by Eiken RI Lab., Tokyo Japan. After dilution of urine with $0.05 \mathrm{M} \mathrm{Na}$ acetate, urinary cyclic AMP was also determined with a radioimmunoassay kit supplied by Hoechst Japan Co., Tokyo, Japan. Serum levels of thyroid hormones and estrogens were also determined by the standard radioimmunoaassy. Other biochemical analyses of blood and urine were performed by routine methods.

\section{Results}

Thyroid state and TSH response to synthetic TRH (Fig. 2)

Serum levels of thyroxine $\left(T_{4}\right)$ and triiodothyronine $\left(\mathrm{T}_{3}\right)$ were $5.1 \pm 0.9 \mu \mathrm{g}$ per 100 $\mathrm{ml}$ and $86.7 \pm 3.5 \mathrm{ng}$ per $100 \mathrm{ml}($ Mean $\pm \mathrm{SEM}$, $\mathrm{n}=3$ ), respectively, which were the lower limits of the normal ranges (normal range; $\mathrm{T}_{4}: 5.0$ $13.0 \mu \mathrm{g}$ per $100 \mathrm{ml}, \mathrm{T}_{3}: 70-230 \mathrm{ng}$ per $100 \mathrm{ml}$ ). There was no clinical sign or symptom of primary hypothyroidism. However, the administration of $500 \mu \mathrm{g}$ TRH evoked an exaggerated TSH response (from basal 7.4 $\mu \mathrm{U}$ per $\mathrm{ml}$ to $37.8 \mu \mathrm{U}$ per $\mathrm{ml}$ at $30 \mathrm{~min}$ ) under a hypocalcemic state: After the serum calcium level was normalized, the TSH response to TRH was decreased (from the basal $2.0 \mu \mathrm{U}$ per $\mathrm{ml}$ to $11 \mu \mathrm{U}$ per $\mathrm{ml}$ at $45 \mathrm{~min}$ ), while serum thyroid hormone levels were not significantly changed $\left(\mathrm{T}_{4}: 5.1 \mu \mathrm{g}\right.$ per $100 \mathrm{ml}, \mathrm{T}_{3}$ : $106 \mathrm{ng}$ per $100 \mathrm{ml})$.

Gonadal state and LH/FSH response to synthetic LH-RH (Fig. 3)

Under hypocalcemic state, serum levels of estrogens (estrone $\left(E_{1}\right)$, estradiol $\left(E_{2}\right)$, and estriol $\left(\mathrm{E}_{3}\right)$ ) at the ovulatory phase of the patient were $22.2 \mathrm{pg}$ per $\mathrm{ml}, 145.0 \mathrm{pg}$ per $\mathrm{ml}$ and $23.2 \mathrm{pg}$ per $\mathrm{ml}$, respectively. These values were within normal limits (normal range at ovulatory phase; $\mathrm{E}_{1}: 20-100 \mathrm{pg}$ per $\mathrm{ml}, \mathrm{E}_{2}$ : 20-150 pg per $\mathrm{ml}, \mathrm{E}_{3}: 5-40 \mathrm{pg}$ per $\mathrm{ml}$ ). The basal levels of LH and FSH were as high as $165 \mathrm{mIU}$ per $\mathrm{ml}$ and $173.0 \mathrm{mIU}$ per $\mathrm{ml}$, respectively. LH response to LH-RH was exaggerated and the peak level of $\mathrm{LH}$ at 45 minutes after the administration of LH-RH was $282.0 \mathrm{mIU}$ per $\mathrm{ml}$. Increment in serum FSH after administration of LH-RH was not so great but serum FSH sustained at high level over 2 hours. Although these high gonadotropins levels with exaggerated responses to LH-RH were compatible with those of primary ovarian failure, serum levels of estrogens were within normal limits and 


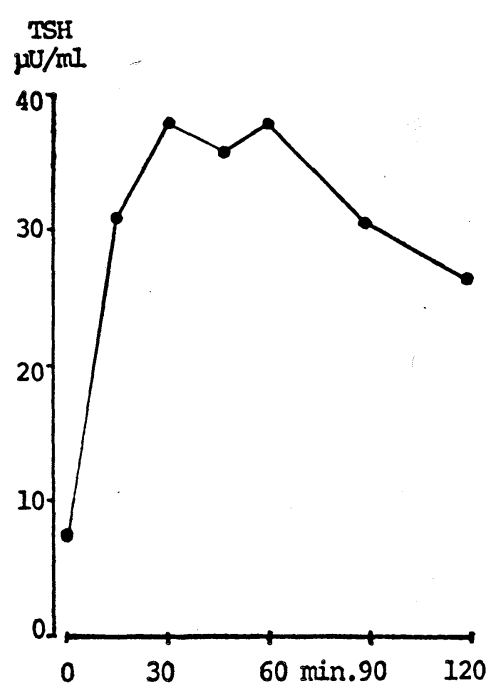

\section{$\stackrel{\text { TSH }}{\mathrm{TU} / \mathrm{ml}}$}

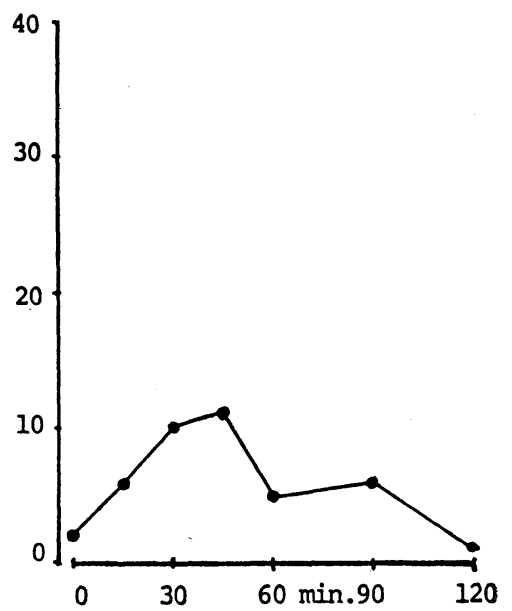

Fig. 2. Thyrotropin response to synthetic TRH under hypocalcemic or normocalcemic state (left; under hypocalcemia, right; under normocalcemia).
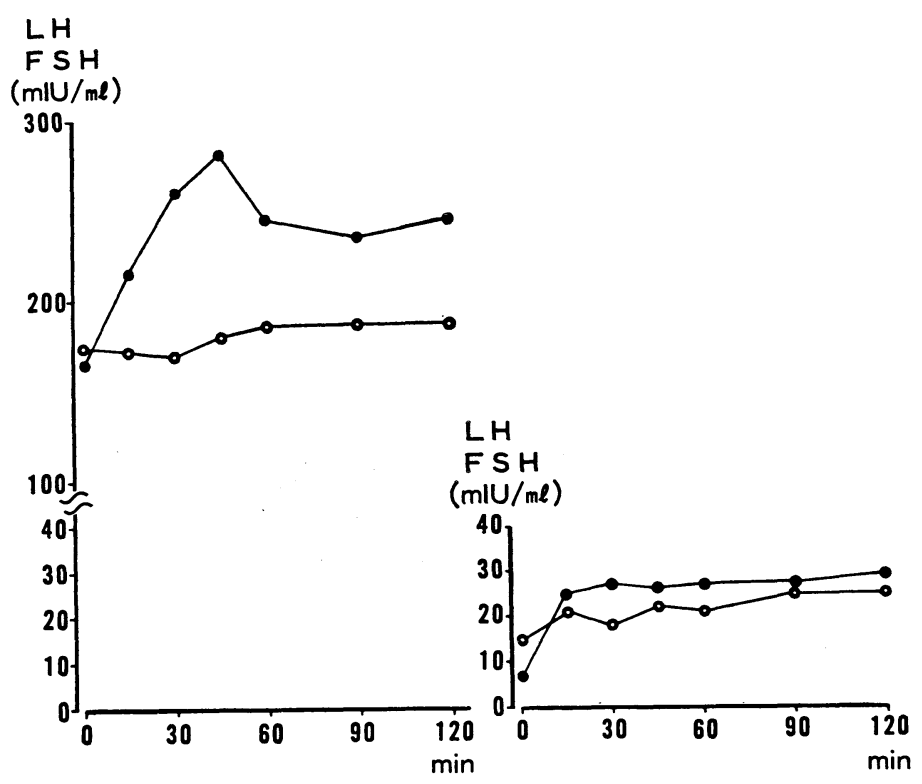

Fig. 3. LH (closed circle) and FSH (open circle) responses to synthetic LH-RH in hypo- or normocalcemic state (left; under hypocalcemia, right; under normocalcemia). also the patient had normal menstrual cycles. In normocalcemia, these abnormal responses to LH-RH were dramatically improved and the basal levels of LH and FSH were lowered to $6.6 \mathrm{mIU}$ per $\mathrm{ml}$ and $15.0 \mathrm{mIU}$ per $\mathrm{ml}$, respectively. Serum levels of estrogens $\left(E_{1}, E_{2}\right.$ and $\mathrm{E}_{3}$ ) at follicular phase were $26.5 \mathrm{pg}$ per $\mathrm{ml}$, $56.7 \mathrm{pg}$ per $\mathrm{ml}$ and $5.2 \mathrm{pg}$ per $\mathrm{ml}$, respectively.
These values were also within normal limits (normal range at follicular phase; $\mathrm{E}_{1}: 10-60$ pg per $\mathrm{ml}, \mathrm{E}_{2}: 10-80 \mathrm{pg}$ per $\mathrm{ml}, \mathrm{E}_{3}: 5-30 \mathrm{pg}$ per $\mathrm{ml})$.

$\mathrm{GH}$ response to arginine- $\mathrm{HCl}$ infusion (Fig. 4)

In a hypocalcemic state, arginine- $\mathrm{HCl}$ failed to evoke a sufficient response of GH. 


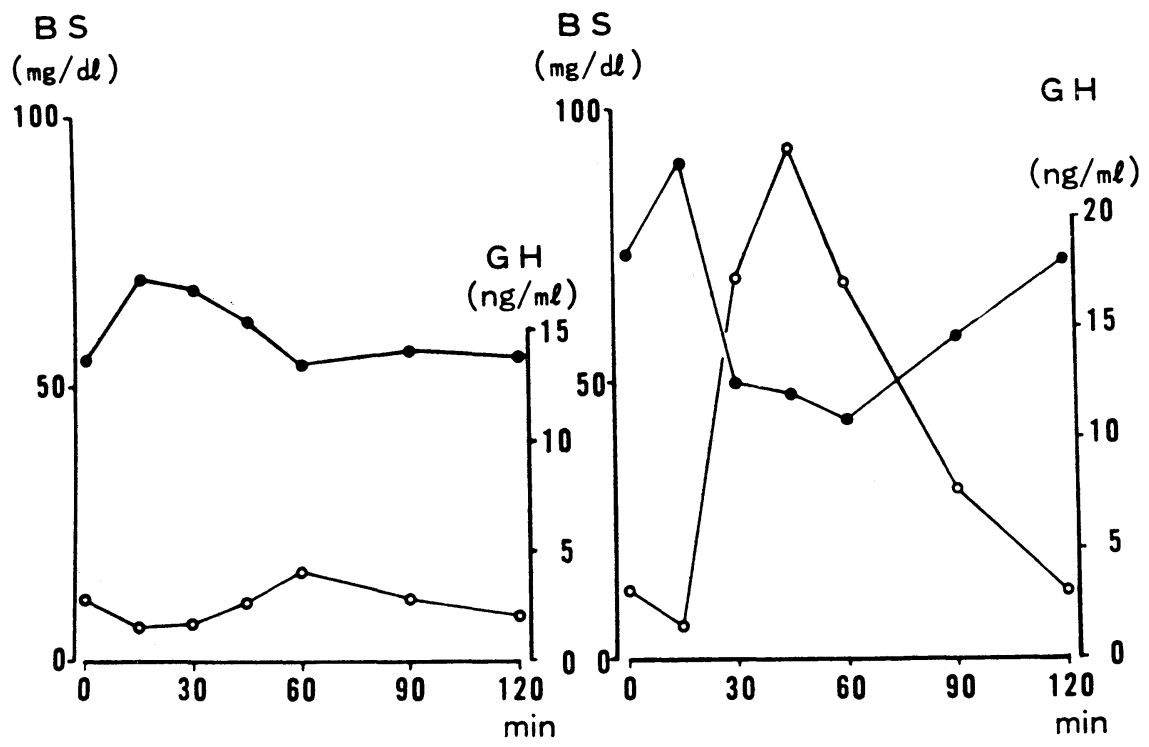

Fig. 4. Growth hormone (open circle) response to arginine- $\mathrm{HCl}$ infusion in hypo- or normocalcemic state (closed circle denotes blood sugar, left; under hypocalcemia, right; under normocalcemia).

GH reached $4.0 \mathrm{ng}$ per $\mathrm{ml}$ at 60 minutes after arginine- $\mathrm{HCl}$ infusion but this increase was less than normal response. After correction of hypocalcemia, the GH response was improved to a maximum $23.1 \mathrm{ng}$ per $\mathrm{ml}$ at 45 minutes after infusion.

\section{Discussion}

In our case, the diagnosis of pseudohypoparathyroidism type I was established on the basis of the typical physical signs, lowered serum calcium and raised serum phosphorus and immunoreactive parathyroid hormone levels, and the resistance of urinary cylic AMP and phosphorus excretion to exogenous parathyroid extract. In spite of almost normal levels of corresponding subordinative hormones, abnormally high secretion of TSH and gonadotropins were supposed to represent the partial resistance of respective target gland to each tropic hormone or the disorder of the negative feedback mechanism in the hypothalamo-pituitary system. These high basal and stimulated secretions of $\mathrm{TSH}, \mathrm{LH}$ and FSH were normalized after the restoration of normocalcemia. Furthermore, blunted GH response which was inconsistent with the report by Urdanivia et al. (Urdanivia et al., 1975) was improved after the restoration of normocalcemia.

Thyroid disorder in patients with pseudohypoparathyroidism which were reported previously, was thought to be caused by TSH deficiency or decreased thyroid reserve (Marx et al., 1971). Recently, Worfsdorf et al. (Worfsdorf et al., 1978) reported a case of pseudohypoparathyroidism associated with hypoestrogenism and elevated basal gonadotropin values. This case also showed a blunted cyclic AMP response to glucagon in serum. Moreover, another case of pseudohypoparathyroidism with elevated serum TSH and gonadotropin levels and their responses to each tropic hormone was reported, in whom thyroid hormones and testosterone levels in serum, however, were normal (Shapiro et al., 1980). In these reports, Worfsdorf et al. and Shapiro et al. hypothesized that the fundamental defect 
in pseudohypoparathyroidism was not in the receptor itself but in the receptor-adenylate cyclase complex since the abnormality in this disorder was not limited to peripheral resistance to parathyroid hormone but was more widespread. Recent studies revealed that the basic abnormality in renal preparation in pseudohypoparathyroidism was though to consist in a nucleotide regulatory unit in the adenylate cyclase system (Marcus et al., 1971, Drezner \& Bruch, 1978). Furthermore, it was reported that the nucleotide regulatory protein was reduced by 45 per cent in erythrocyte membranes of five of ten pseudohypoparathyroid patients (Farfel et al., 1980), indicating that in some patients with this disorder the abnormalities consist of a generalized defect in hormone-sensitive adenylate cyclase rather than in the parathyroid hormone receptor itself.

It has been postulated that an increase in the calcium concentration in the cell cytoplasm may be responsible for the activation of enzymatic reactions ultimately leading to the physiological reaction (Rasmussen, 1970) and that from many in vitro studies the calcium influx from extracellular fluids appears to play an important role in the mechanism and in the appearance of the hormonal effect (Nagata \& Rasmussen, 1970; Eto et al., 1974; Eto \& Fleisher, 1976). It has also been postulated that diminished phosphaturic response to exogenously administered parathyroid extract was restored after treatment of calcium administration or vitamin $\mathrm{D}$ in patients with pseudohypoparathyroidism (Suh et al., 1970; Rodriguez et al., 1974; Stögmann \& Fischer, 1975). Rodriguez et al. supposed that the metabolic defect in pseudohypoparathyroidism was an impaired calcium peameability of cell membrane in response to PTH.

In our case, multiple abnormalities of anterior pituitary hormone secretion, which was similar to the case of Shapiro et al. or Worfsdorf et al. were improved after the restoration of normocalcemia following the administration of $1 \alpha$-hydroxy-cholecalciferol. It is not clear whether this improvement in pituitary hormone secretion was due to the elevation of the serum calcium level or to the administration of $1 \alpha$ hydroxy-cholecalciferol itself. In the light of many experimental and clinical reports which were concerned with the importance of calcium in the mechanism of hormone secretion or the appearance of hormonal effect, pituitary abnormalities in our case might be considered to be a functional disorder originating in a hypocalcemic state rather than genetic abnormalities such as the reduction of the nucleotide regulatory protein.

\section{References}

Albright, F., Burnett, C. H., Smith, P. H., and Parson, W. (1942). Pseudohypoparathyroidism-an example of "Seabright-Bantam Syndrome". Endocrinology 30, 922-932.

Carlson, H. E., Brickman, A. S., and Bottazo, G. F. (1977). Prolactin deficiency in pseudohypoparathyroidism. N. Engl. J. Med. 296, 140-144.

Chase, L. R., Melson, G. L., and Aurbach, G. D. (1969). Pseudohypoparathyroidism; defective excretion of $3^{\prime}, 5^{\prime}$-AMP in response to parathyroid hormone. J. Clin. Invest. 48, 1832-1844.

Drezner, M. K., and Burch, W. M. Jr. (1978). Altered activity of the nucleotide regulatory site in the parathyroid hormone-sensitive adenylate cyclase from the renal cortex of a patient with pseudohypoparathyroidism. J. Clin. Invest. 62, 1222-1227.

Drezner, M., Neelon, F. A., and Levovitz, H. E. (1973). Pseudohypoparathyroidism type II: A possible defect in the recption of the cyclic AMP signal. $N$. Engl. J. Med. 289, 1056-1060.

Eto, S., and Fleischer, N. (1976). Regulation of thyrotropin (TSH) release and production in monolayer cultures of transplantable TSH-producing mouse tumors. Endocrinology 98, 114-122.

Eto, S., Wood, J. M., Hutchins, M., and Fleischer, N. (1974). Pituitary ${ }^{45} \mathrm{Ca}^{++}$uptake and release of ACTH, GH and TSH: effect of verapamil. Am. J. Physiol. 226, 1315-1320.

Farfel, Z., Brickman, A. S., Kaslow, H. R., Brothers, V. M., and Bourne, H. R. (1980). Defect of receptorcyclase coupling protein in pseudohypoparathyroidism. N. Engl. J. Med. 303, 237-242.

Marcus, R., Wilber, J. F., and Aurbach, G. D. (1971). Parathyroid hormone-sensitive adenyl cyclase from the renal cortex of a patient with pseudohypoparathyroidism. J. Clin. Endocrinol. Metab. 33, 537-541.

Marx, S. J., Hershman, J. M., and Aurbach, G. D. (1971). Thyroid dysfunction in psuedohypoparathy- 
roidism. J. Clin. Endocrinol. Metab. 33, 822-828.

Nagata, N., and Rasmussen, H. (1970). Parathyroid hormone, 3',5'-AMP, $\mathrm{Ca}^{++}$, and renal gluconeogenesis. Proc. Natl. Acad. Sci. USA 65, 368-374.

Rasmussen, H. (1970). Cell communication, calcium ion, and cyclic adenosine monophosphate. Science 170, 404-412.

Rodriguez, H. J., Villarreal, H. Jr., Klahr, S., and Slatopolsky, E. (1974). Pseudohypoparathyroidism type II: Restoration of normal renal responsiveness to parathyroid hormone by calcium administration. J. Clin. Endocrinol. Metab. 39, 693-701.

Shapiro, M. S., Bernheim, J., Gutman, A., Arber, I., and Spitz, I. M. (1980). Multiple abnormalities of anterior pituitary hormone secretion in association with pseudohypoparathyroidism. J. Clin. Endocrinol. Metab. 51, 483-487.

Stögman, W., and Fischer, J. A. (1975). Pseudohypoparathyroidism, disappearance of the resistance to parathyroid extract during treatment with vitamin $\mathrm{D}$. Am. J. Med. 59, 140-144.

Suh, S. M., Fraser, D., and Kooh, S. W. (1970). Pseudohypoparathyroidism: responsiveness to parathy- roid extract induced by vitamin D therapy. J. Clin. Endocrinol. Metab. 30, 609-614.

Urdanivia, E., Mataverda, A., and Cohen, M. P. (1975). Growth hormone secretion and sulfation factor activity in pseudohypoparathyroidism. J. Lab. Clin. Med. 86, 772-776.

Werder, E. A., Illig, R., Bernasconi, S., Kind, H., and Prader, A. (1975). Excessive thyrotropin response to thyrotropin-releasing hormone in pseudohypoparathyroidism. Pediatr. Res. 9, 12-16.

Winnacker, J. L., Becker, K. L., and Moore, C. F. (1967). Pseudohypoparathyroidism and selective deflciency of thyrotropin: an interesting association. Metabolism 16, 644-650.

Wolfsdorf, J. I., Rosenfield, R. L., Fang, V. S. Kobayashi, R., Razdan, A. K., and Kim, M. H. (1978). Partial gonadotropin-resistance in pseudohypoparathyroidism. Acta. Endocrinol. 88, 321-328.

Zisman, E., Lotz, M., Jenkins, M. E., and Bartter, F. C. (1969). Studies in pseudohypoparathyroidism: Two new cases with a probable selective deficiency of thyrotropin. Am. J. Med. 46, 464-471. 